\title{
Excretion of laccase by sycamore (Acer pseudoplatanus L.) cambial cells: effect of copper deficiency, reversible removal of type $2 \mathrm{Cu}^{2+}$
}

\author{
J. Quinton-Tulloch ${ }^{1}$, J. Gaillard², J. Jordanov ${ }^{2}$, R. Bligny ${ }^{1}$ \\ and R. Douce ${ }^{1}$
}

CEN-G et Université Joseph-Fourier, DRF/PCV 1 and DRF/SCPM ${ }^{2}, 85 X, F-38041$ Grenoble Cedex, France

\section{Introduction}

Cambial cells of sycamore excrete a laccase-type polyphenol oxidase (EC 1.10.3.1) (Bligny and Douce, 1983). This type of enzyme, which utilizes molecular oxygen to oxidize phenolic substrates, is probably involved in lignin degradation processes (Mayer and Harel, 1979). This polyphenol oxidase is excreted by many mycorrhizal fungi (for a review, see Mayer, 1987) and is present in some higher plant cells including the genus Rhus (Rhus vernicifera, see Reinhammar, 1970), Aesculus (Wosilait et al., 1954) and Prunus (Lehman et al., 1974). The enzyme was purified from the nutrient medium, into which it was excreted by suspension-cultured sycamore cells, using classical purification techniques including a concanavalin A-Sepharose affinity column. The sycamore cell laccase is a monomeric blue copper protein containing $45 \%$ carbohydrate and 4 copper atoms (one type 1 and $2 \mathrm{Cu}^{2+}$ and two type $3 \mathrm{Cu}^{2+}$ ) per molecule. The molecular mass $\left(M_{\mathrm{r}}=\right.$
$97000)$ was calculated from the sedimentation coefficient $\left(s_{20, W}=6.1 \mathrm{~S}\right)$, the diffusion coefficient $\left(D_{20, w}=5.3\right)$, and the partial specific volume $(\bar{v}=0.71)$. The specific activity of the purified enzyme measured at $\mathrm{pH} 6.6$ (optimum $\mathrm{pH}$ ) and in the presence of $20 \mathrm{mM} 4$-methylcatechol (optimum substrate conditions) corresponds to an oxygen uptake of at least $32 \mu \mathrm{mol}$ of consumed $\mathrm{O}_{2} / \mathrm{min} / \mathrm{mg}$ of protein. The structure of the protein is stabilized by asparagine-linked oligosaccharides, which are a series of recurrent xylose-containing biantennary complexes that share at the core a common structural unit, i.e., $\mathrm{Xyl} \beta$ $1 \rightarrow 2(\operatorname{Man} \alpha 1 \rightarrow 6) \operatorname{Man} \beta 1 \rightarrow 4 \mathrm{GicNAc} \beta$ $1 \rightarrow 4$ (Fuc $\alpha 1 \rightarrow 3$ ) GlcNAc (Takahashi et al.,1986). The laccase excreted by the cells corresponded to ca $2 \%$ of the total protein synthesized during cell growth. The molecules are synthesized at the level of the endoplasmic reticulum where $\mathrm{Cu}$ atoms are probably incorporated and in the Golgi cisternae where the protein matures (glycosylation). The excretion process is inhibited by $1 \mu \mathrm{M}$ monensin. 


\section{Effects of a copper deficiency}

The total amount of active laccase excreted by sycamore cells was closely proportional to the amount of copper initially present in the culture medium (in the range of 2-100 $\mu \mathrm{g}$ of copper/ of nutrient medium, Bligny et al., 1986). Copperdeprived cells excreted the apolaccase (laccase without copper, inactive) at the same rate as copper-supplied cells excrete the active laccase (hololaccase). The concentrated apolaccase $(100 \mathrm{mg} / \mathrm{ml})$

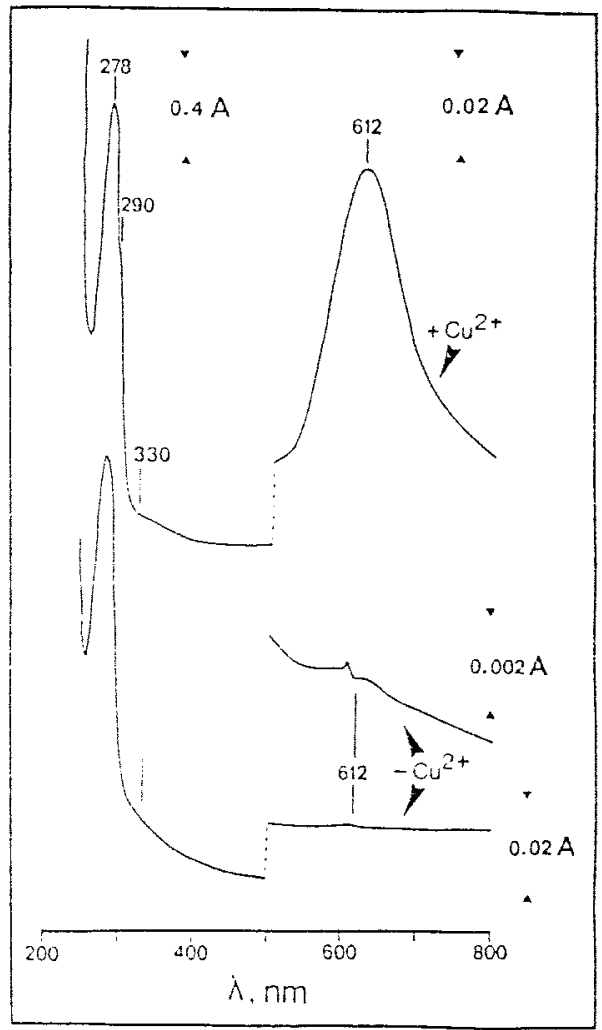

Fig. 1. Room-temperature absorption spectra of sycamore cell holdaccase $\left(+\mathrm{Cu}^{2+}\right)$ and apolaccase $\left(-\mathrm{Cu}^{2+}\right)$. Solutions containing $2.5 \mathrm{mg}$ of laccase $\left(+\mathrm{Cu}^{2+}\right)$ or $2.5 \mathrm{mg}$ of apolaccase $\left(-\mathrm{Cu}^{2+}\right)$ per $\mathrm{ml}$ were used. Optical path length, $10 \mathrm{~mm}$ (quartz cuvettes).

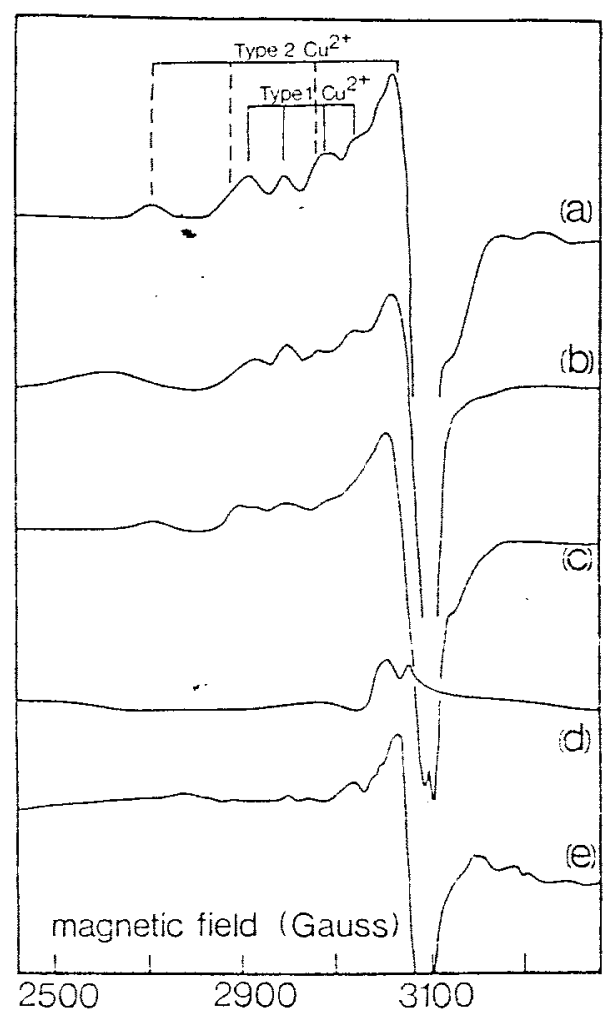

Fig. 2. EPR spectra at $40 \mathrm{~K}$ and $9.25 \mathrm{GHz}$ of sycamore cell hololaccase and apolaccase subjected to different treatments. a: hololaccase $(12 \mathrm{mg} / \mathrm{ml})$; b: type 2 $\mathrm{Cu}^{2+}$-depleted hololaccase (T2D-laccase, $17 \mathrm{mg} / \mathrm{ml}$ ); c: reconstituted T2D-laccase $(6 \mathrm{mg} / \mathrm{ml})$; $d$ : apolaccase (25 $\mathrm{mg} / \mathrm{ml}$ ); e: copper insertion assay in apolaccase (18 $\mathrm{mg} / \mathrm{ml}$ ).

has a slightly yellow color contrasting with the deep blue color of hololaccase. As shown in Fig. 1, the absorption spectra of apolaccase showed a striking loss of absorption at 612 and $330 \mathrm{~nm}$ corresponding, respectively, to a strong decrease of type 1 and type 3 copper atoms. In addition, the EPR spectra (Fig. 2) show that the type 2 copper decreased in the same proportion. Addition of $2 \mu \mathrm{M}$ copper to copper-deficient cultures triggers the excretion of hololaccase after a 5 $h$ lag phase, corresponding to the time for 
maturation and excretion of the enzyme including the time necessary for incorporation of $\mathrm{Cu}$ into the catalytic center.

\section{Preparation of type $2 \mathrm{Cu}^{2+}$ (T2D) syca- more cell laccase; reconstitution assays}

The type 2 copper atom was removed from the hololaccase according to the method of Morpurgo et al. (1980). $75 \mu \mathrm{M}$ laccase was dialyzed for $12 \mathrm{~h}$ under anaerobiosis, against solution $\mathrm{A}$, containing $2 \mathrm{mM}$ dimethylglyoxime, $2 \mathrm{mM}$ potassium ferrocyanide and $50 \mathrm{mM}$ sodium acetate buffer, $\mathrm{pH}$ 5.2. After the first $8 \mathrm{~h}, 1 \mathrm{mM}$ EDTA was added to solution $A$. The sample was then dialyzed anaerobically 3 times for $5 \mathrm{~h}$ against a rinsing solution containing $0.1 \mathrm{M}$ phosphate buffer, pH 6.0.

After the first experiment, $50 \%$ of the type $2 \mathrm{Cu}^{2+}$ was removed. Then the experiment was repeated and the type 2 $\mathrm{Cu}^{2+}$ was reduced to $\mathrm{ca} 20 \%$. Optical and EPR spectra showed that the type 1 and 3 $\mathrm{Cu}^{2+}$ were not removed. Under these conditions, it was observed that the specific activity of this T2D-laccase was reduced to $6.5 \mu \mathrm{mol}$ of $\mathrm{O}_{2}$ consumed/ $\mathrm{min} / \mathrm{mg}$ protein, i.e., to about $20 \%$ of the normal value. This indicates that the specific activity of sycamore cell laccase strictly depends upon the presence of the type $2 \mathrm{Cu}^{2+}$. This result was confirmed by reconstitution assays. The type $2 \mathrm{Cu}^{2+}$ was reintroduced into the molecules of T2D-laccase in assays adapted from the method of Malkin et al. (1969). $25 \mu \mathrm{M}$ T2D-laccase was anaerobically incubated for $1 \mathrm{~h}$ in solution $\mathrm{B}$, containing $30 \mathrm{mM}$ ascorbic acid, $50 \mu \mathrm{M}$ copper sulfate and $10 \mathrm{mM}$ sodium citrate, $\mathrm{pH}$ 6.0. The samples were then dialyzed for $20 \mathrm{~h}$ at $4^{\circ} \mathrm{C}$ against 2 changes of $25 \mathrm{mM}$ potas- sium phosphate + $1 \mathrm{mM}$ EDTA, pH 6.0, and concentrated by ultrafiltration (Diaflo XM50 membrane). As shown in Fig. 2, the type $2 \mathrm{Cu}^{2+}$ alom was reincorporated into the T2D-laccase. Measurements of enzymic activity showed, therefore, that the specific activity of the reconstituted enzyme (35 $\mu \mathrm{mol}$ of $\mathrm{O}_{2}$ consumed $/ \mathrm{min} / \mathrm{mg}$ protein) was fully recovered.

\section{Copper introduction assays in syca- more cell apolaccase}

In order to introduce the type $2 \mathrm{Cu}^{2+}$ (and possibly the ty'pe 1 and $3 \mathrm{Cu}^{2+}$ ) into the copper-free laccase, we subjected the apolaccase to the same experiments as described above for the T2D-laccase. Surprisingly, it was not possible to introduce the type $2 \mathrm{Cu}^{2+}$ into the copper-free laccase. The only modification observed on EPR spectra could correspond to copper atoms bound to the protein at non-specific sites. No enzymatic activity was detected in solutions of apolaccase subjected to copper introduction experiments.

In conclusion, since type $2 \mathrm{Cu}^{2}+$ could be incorporated into T2D-laccase and not into apolaccase, it is possible that the presence of type 1 and $3 \mathrm{Cu}^{2+}$ is necessary for the type $2 \mathrm{Cu}^{2+}$ to be incorporated into the glycosylated apoprotein.

\section{References}

Bligny R. \& Douce R. (1983) Excretion of laccase by sycamore (Acer pseudoplatanus L.) cells - purification and properties of the enzyme. Biochem. J. 209, 489-496

Bligny R., Gaillard J. \& Douce R. (1986) Excretion of laccase by sycamore (Acer pseudoplatanus L.) cells - effects of a copper deficiency. Biochem. J. 237, 583-588 
Lehman E., Harel E. \& Mayer A.M. (1974) Copper content and other characteristics of purified peach laccase. Phytochemistry 13, 1713-1717

Malkin R., Malmstrom B.G. \& Vanngard T. (1969) The reversible removal of one specific copper (II) from fungal laccase. Eur. J. Biochem. 7, 253-259

Mayer A.M. (1987) Polyphenol oxidases in plants - recent progress. Phytochemistry 26, 11-20

Mayer A.M. \& Harel E. (1979) Polyphenol oxidases in plants. Phytochemistry 18, 193-215

Morpurgo L., Graziani M.T., Finazzi-Agrò A., Rotilio G. \& Mondovi B. (1980) Optical proper- ties of Japanese lacquer tree (Rhus vernicife ra) laccase depleted of type 2 copper (II). Biochem. J. 187, 361-366

Reinhammar B. (1970) Purification and properties of laccase and stellacyanin from Rhus vernicifera. Biochim. Biophys. Acta 205, 35-47

Takahashi N., Hotta T., Ishihara H., Mori M., Bligny R., Akazawa T., Endo S. \& Arata Y. (1986) Xylose-containing common structural unit in $\mathrm{N}$ linked oligosaccharides of laccase from sycamore cells. Biochemistry 25, 388-395

Wosilait W., Nason A. \& Terrell A.J. (1954) Pyridine nucleotide-quinone reductase II. J. Biol. Chem. 206, 271-282 